Acta Protozool. (2018) 57: 231-242 www.ejournals.eu/Acta-Protozoologica doi:10.4467/16890027AP.18.017.10093 PROTOZOOLOGICA

\title{
Population Dynamics of Amoeboid Protists in a Tropical Desert: Seasonal Changes and Effects of Vegetation and Soil Conditions
}

\author{
Horacio Pérez-Juárez ${ }^{1,2,3}$, Angélica Serrano-Vázquez ${ }^{1,3}$, Enrique Lara ${ }^{4}$, Cecilia Ximénez ${ }^{3}$, Héctor \\ Godínez-Alvarez $^{5}$, Salvador Rodríguez-Zaragoza ${ }^{1}$, Luis E. Eguiarte ${ }^{6}$, Mayra M. Hernández \\ Moreno $^{7}$, Leonardo D. Fernández ${ }^{8}$, Liliana Rojas-Velázquez ${ }^{2,3}$, Patricia Morán ${ }^{3}$, Mariela Castillo ${ }^{1}$, \\ Víctor M. Rivera Aguilar ${ }^{1}$
}

\footnotetext{
${ }^{1}$ Laboratorio de Ecología Microbiana, Unidad de Biotecnología y Prototipos, Facultad de Estudios Superiores, Iztacala, Universidad Nacional Autónoma de México, México

${ }^{2}$ Doctorado en Ciencias Biomédicas, Universidad Nacional Autónoma de México, México

${ }^{3}$ Laboratorio de Inmunología, Unidad de Investigación en Medicina Experimental, Facultad de Medicina, Universidad Nacional Autónoma de México, México

${ }^{4}$ Real Jardín Botánico, CSIC, Madrid, España

${ }^{5}$ Laboratorio de Ecología, Unidad de Biotecnología y Prototipos, Facultad de Estudios Superiores, Iztacala, Universidad Nacional Autónoma de México, México

${ }^{6}$ Departamento de Ecología Evolutiva, Instituto de Ecología, Universidad Nacional Autónoma de México, México

${ }^{7}$ Laboratorio de Edafología, Unidad de Biotecnología y Prototipos, Facultad de Estudios Superiores, Iztacala, Universidad Nacional Autónoma de México, México

${ }^{8}$ Centro de Investigación en Recursos Naturales y Sustentabilidad (CIRENYS), Universidad Bernardo O’Higgins, Santiago, Chile
}

\begin{abstract}
In arid environments, protist diversity is higher in soil covered by vegetation than in bare soil and is also likely to vary in line with the marked seasonal patterns; however, these patterns have not been explored in detail in arid zones. Herein, we used culture - and morphological-based approaches to describe patterns of amoeboid protist diversity in vegetated and bare soil areas from the intertropical desert of Tehuacán, Mexico, during dry and wet seasons. Overall, 27 protist species belonging to Amoebozoa, Discoba and Rhizaria were retrieved using culture-dependent methods. Among the soil protist groups found, Discoba (principally represented by Heterolobosea) was always the most prevalent taxa. Protist diversity was different between soil with vegetation and bare soil, principally during the dry season. Moreover, the electrical conductivity and $\mathrm{pH}$ of the soil were correlated with the protist species during the wet season. Our results support the hypothesis that soil protist diversity patterns exhibit a seasonal variation between dry and wet seasons. This seasonal variation likely relies on water availability, although the role of other environmental factors cannot be completely ruled out. In addition, the soils with vegetation could be a refuge for the amoeboid protists during the harsh soil conditions of dry seasons.
\end{abstract}

Keywords: Heterolobosea, seasonal variation, soil microhabitat, soil protist, Tehuacán desert

Address for correspondence: Horacio Pérez-Juárez: Circuito de Posgrado s/n, Coyoacán, Cd. Universitaria, 04510, Ciudad de México, CDMX.daztlan13@hotmail.com; Cecilia Ximénez: Dr. Balmis No.148 Col. Doctores, Ciudad de México, México, C.P. 06726.cximenez@ unam.mx; Salvador Rodríguez: Avenida de los Barrios \#1, Los Reyes Iztacala, Tlalnepantla, Estado de México, C.P. 54090. srodrige@ unam.mx 


\section{INTRODUCTION}

Amoeboid protists constitute the most diverse functional category in soils (Geisen et al. 2018); they play a major role in nutrient cycling by preying on bacteria (Bonkowski 2004), fungi (Geisen et al. 2016) and algae (Seppey et al. 2017), subsequently releasing labile nutrients available for other microorganisms and plants into the soil (Geisen et al. 2017).

Although the protists are dependent on the availability of water (Anderson 2000, Griffiths et al. 2001), desert soils host many amoeboid protists despite their low moisture and nutrient contents (Robinson et al. 2002, Perez-Juárez et al. 2017). While many soil factors drive their distribution at a local scale (e.g., $\mathrm{pH}$ and nutrients) (Geisen et al. 2014, Lanzén et al. 2016), water availability seems to always be the most limiting factor in arid soils (Whitford 2002). This is why the harshness of arid soils is exacerbated during dry seasons, and many amoeboid protists withstand the challenges of low water availability and UV radiation prevailing in dry seasons only in soils covered with vegetation, as plants contribute to keeping water and nutrient levels relatively constant in the arid soil (Barness et al. 2009, Li et al. 2011, Sylvain and Wall 2011). Indeed, evidence shows that in arid soils, unicellular diversity tends to be higher in soils covered by vegetation than in bare soils (Robinson et al. 2002; Rodríguez-Zaragoza and Steinberger 2004; Rodríguez-Zaragoza et al. 2005 a, b; Bamforth 2008; Barness et al. 2009; Fernández 2015). Additionally, many protists simply cannot survive in an active state without water (Bamforth 1963); therefore, arid soils in dry seasons filter only taxa with physiological and morphological traits adequate to withstand the lack of water (Austin et al. 2004, Geisen et al. 2014, Fernandez 2015). Most of these species, however, can withstand long periods of dormancy spent as cysts, a coccoid form that can withstand adverse conditions, including drought (Geisen et al. 2014). Protist cysts from various species differ in their structure, ontogeny and surface properties (Foissner 2011) and probably also in their resistance to the harsh conditions encountered during the dry season.

This study was conducted in the intertropical desert of Tehuacán in Mexico. This desert is regarded as a biodiversity hotspot (Davila et al. 2002), harboring even an endemic soil protist species (i.e., a testate amoeba species, Pérez-Juárez et al. 2017). In this desert, the vegetation is dominated by Prosopis laevigata and
Parkinsonia praecox (Fabaceae). Both species exhibit a patchy distribution interspersed with wide areas of bare soil. The two shrubs have ecophysiological features that may affect soil in different ways and can create microenvironments in the soil under their canopies, protecting it also from the climate of the desert that includes long periods of drought, typically interrupted by a short wet season (Barness et al. 2009; SerranoVázquez et al. 2013)

In this context, we described the patterns and underlying causes driving amoeboid protist diversity in soils with vegetation and in bare soil areas during the dry and wet season in Tehuacán, an intertropical desert in Central Mexico. To do this, we used culture - and morphological-based approaches. The morphological-based approaches are valid for identifying ameboid protists because amoeboid protists are a polyphyletic group of eukaryotic unicellular organisms that use pseudopodia (i.e., extensions of cytoplasm) for movement and feeding. Pseudopodia vary in shape among taxa and, therefore, along with differences in patterns of locomotion, are regarded as valuable morphological traits to classify these protists into different groups (Fahrni et al. 2003; Pawlowski and Burki 2009).

Therefore, we posit that the temporal dynamics of soil amoeboid protist populations can follow two patterns to be tested in our research: (1) Species are homogeneously distributed during the dry season, and less resistant populations decrease considerably in the bare soils but persist underneath plants, which act as a refuge. (2) Alternatively, all species present may have developed similar resistance mechanisms, and consequently, biodiversity remains unaltered. In this manuscript, we tested the likeliness of both scenarios and whether the first was retained. Additionally, we determined whether there was an effect of other related variables, such as soil characteristics and soil depth, on amoeboid protist species.

\section{MATERIAL AND METHODS}

\section{Study area}

Tehuacán Valley is a semiarid desert formed by the rain shadow effect of the Sierra Madre Oriental (Villaseñor et al. 1990). Alluvial terraces deposited by the Salado River constitute local landscapes with relatively flat surfaces and deep soils (López-Galindo et al. 2003). The predominant soil units are calcareous regosols and fluvisols, according to FAO-WRB (López-Galindo et al. 2003). Our study site is located in Zapotitlán Salinas between $18^{\circ} 12^{\prime}$ and 
$18^{\circ} 25^{\prime} \mathrm{N}$ and $97^{\circ} 24^{\prime}$ to $97^{\circ} 25^{\prime} \mathrm{W}$. The annual mean temperature is $21{ }^{\circ} \mathrm{C}$, and the precipitation is between $400-450 \mathrm{~mm}$. The vegetation in the alluvial terraces is dominated by shrubs of Pr. laevigata (Humb. \& Bonpl. ex Willd.) MC Johnst and Pa. praecox (Ruiz \& Pav.) Hawkins (Osorio-Beristain et al. 1996, Valiente-Banuet et al. 2000, Serrano-Vázquez et al. 2013). Both species form shrub patches that alternate with large areas of bare soil (Fig. 1). Prosopis laevigata and $\mathrm{Pa}$. praecox play key ecological roles because they provide a suitable habitat for other plants, microorganisms, birds, rodents, and insects that are critical for such processes as organic matter decomposition, seed dissemination, pollination, and plant establishment in the Tehuacán desert (Valiente- Banuet et al. 2000).

\section{Sampling}

Three individual organisms of Pr. laevigata and three of $\mathrm{Pa}$. praecox with similar morphological characteristics (3-3.5 $\mathrm{m}$ height, 2.5-2.9 m canopy diameter, and $0.2-0.3 \mathrm{~m}$ basal diameter), along with three bare soil sites in an alluvial terrace were selected (hereafter referred to as microhabitats). For each microhabitat, we collected soil samples during the wet season (September 2008; 27 samples) and dry season (May 2009; 27 samples). The soil samples were collected using a stainless steel corer $(10 \mathrm{~cm}$ in diameter) beneath each selected shrub and from bare soil areas. Soil samples were collected from 0 to $30 \mathrm{~cm}$ deep in soil layers of $10 \mathrm{~cm}$ ( 0 to 10,10 to 20 and 20 to $30 \mathrm{~cm}$ ). A total of 54 soil samples were collected (three microhabitats by three replicates by three depths by two seasons $=54$ ) and stored in self-sealing bags. Bags were deposited in a camp cooler to avoid overheating and stored at $4{ }^{\circ} \mathrm{C}$, after measuring the soil moisture and obtaining subsamples for soil amoeboid protists, until processing for the next analyses.

\section{Physical and chemical soil properties}

To examine the roles of two legume shrubs on amoeboid protist communities, we evaluated how Pr. laevigata and Pa. praecox modify the soil conditions in the first $30 \mathrm{~cm}$ of depth (in $10 \mathrm{~cm}$ intervals). All soil samples were analyzed separately for each physical and chemical property. The soil moisture content was determined by the gravimetric method after arriving at the laboratory (weighing samples before and after drying them at $110^{\circ} \mathrm{C}$ for $72 \mathrm{~h}$; Ortiz and Ortiz 1980). The soil composition (percentage of sand, silt, and clay) was determined using a hydrometer with a method described by Bouyoucos (1962). This method takes into account the precipitation time of the particles and temperature (Medina et al. 2007). The $\mathrm{pH}$ was determined in a 1:2.5 soil solution in distilled water (Bates 1954, Willard et al. 1958) using a potentiometer (Conductronic $\mathrm{pH}$ 120, pH Electrode BA17; Boeco, Hamburg, Germany). Electrical conductivity was determined from a soil extract with a soluble salt tester (Mark Kelway, model SST, Kel Instruments Co., Inc., Wyckoff, NJ, USA) following the manufacturer's instructions. Organic matter content was measured using humid combustion as described by Walkley and Black (1934) and available phosphorus (orthophosphates) based on Olsen's (1954) extraction method, using $\mathrm{NaHCO}_{3}$ as the extractant (Cajuste 1986).

\section{Isolation and identification of amoeboid protists}

We obtained the amoeboid protists in triplicate for each soil sample immediately after arriving at the laboratory. All soil samples were analyzed separately. One gram of dry soil for each sample was added to $10 \mathrm{ml}$ of 1:5 soil extract, and the suspension was thoroughly mixed by vortexing for five 15 -s pulses in screw-capped glass test tubes. This suspended sample was then left untouched for $15 \mathrm{~min}$ to allow the sedimentation of heavy particles (Rodríguez-Zaragoza et al. 2005a). All the supernatant was then gently transferred onto bacteria-free nonnutritive agar plates (Rodríguez-Zaragoza et al. 2005a).

The amoeboid protists were allowed to settle on the agar for 2 $\mathrm{h}$ before withdrawal of the excess water, and both trophozoites and cysts were completely isolated with a Pasteur pipette, pulling out the end after heating it on a Bunsen flame to capture cells or cysts one by one, as described in Smirnov and Brown (2004). The same person carried out a intentional, nonbiased and exhaustive sampling to select the amoeboid protists. All picked cells or cysts were individually transferred to new nonnutrient agar plates with soil extract to allow for their proliferation, and they later were identified after seven days of incubation at $28.5^{\circ} \mathrm{C}$. Amoeboid protist species were placed under a coverslip and morphologically identified using an Olympus $\mathrm{CH} 2$ phase contrast microscope based on classical amoeboid protist identification textbooks. The main bibliographic sources used in this study were Brown and De Jonckheere (1999), Page (1976), Page (1988), and Smirnov and Brown (2004). It is important to note that the optical resolution of the method used was lower than that of others; however, it is a practical method for cultures of amoeboid protists (Smirnov and Brown 2004).

We prepared the soil extract by suspending $200 \mathrm{~g}$ of soil collected at each site in $1000 \mathrm{~mL}$ of distilled water and heating the mixture to $60^{\circ} \mathrm{C}$ in a water bath for $6 \mathrm{~h}$, then filtering it through a Whatman paper number 41 and autoclaving it for $15 \mathrm{~min}$ at $121^{\circ} \mathrm{C}$ and $1.1 \mathrm{~kg}$ $\mathrm{cm}^{-2}$ pressure. The final solution was then stored at $4{ }^{\circ} \mathrm{C}$ until use (Rodríguez-Zaragoza et al. 2005b).

\section{Data analyses}

The soil parameters such as moisture, organic matter content and percentage of sand, silt and clay were arcsine square root transformed to meet the assumptions of normality and equality of variances. The variance in soil data was analyzed with nested linear mixed effects models, in which season and habitat within season were considered fixed factors and soil depth within habitat was considered as a random factor. The models were fitted with the JMP statistical software version 8.0 (SAS Institute Inc., Cary, North Carolina, USA).

Based on morphological identification, we constructed a presence-absence matrix with all amoeboid species recorded in all samples analyzed. These data were used to evaluate the following parameters: 1) variation in richness of amoeboid protists by microhabitat and 2) relationship between richness of amoeboid protists and physical and chemical parameters of soil in each microhabitat. The richness of amoeboid protists was compared among microhabitats by constructing accumulation curves for each season. We estimated these curves with confidence intervals of $95 \%$ with the program EstimateS version 9 (Colwell 2013).

The Sørensen $(2 \mathrm{c} / \mathrm{a}+\mathrm{b})$ method was employed to compare the similarity in the communities of amoeboid protists in the two seasons analyzed.

We analyzed the correlation between amoeboid protist composition in the three previously selected microhabitats and the soil parameters using canonical correspondence analysis (CCA). For each season, we constructed one matrix of microhabitat samples 
by amoeboid protists and another matrix of microhabitat samples by soil parameters. Amoeboid protists recorded only once were excluded from the analysis to avoid bias by rare protists. Analyses were performed using the envfit function implemented in the vegan package using $\mathrm{R}$ software version 2.9 (Oksansen et al. 2013).

\section{RESULTS}

\section{Physical and chemical soil parameters}

The physical and chemical soil parameters varied according to season, microhabitat and soil depth. In general, soil had a loamy clay texture. Soil moisture was lower than $20 \%$. The electrical conductivity showed values less than 1 mmhos $\mathrm{cm}^{-1}$; and the $\mathrm{pH}$ remained slightly basic. The contents of organic matter and available phosphorus were poor in all microhabitats. There were significant differences in the soil moisture, $\mathrm{pH}$, sand and silt content between microhabitats during both dry and wet seasons, while organic matter was only significantly different in the dry season (Tables 1-2).

\section{Richness of amoeboid protists}

Amoeboid protist was composed of species belonging to Amoebozoa, Discoba and Rhizaria. This composition varied according to season and microhabitat. However, species of Discoba (i.e., eruptive amoebae sensu Smirnoff and Brown 2004; Adl et al. 2018 ) were observed in all microhabitats in two seasons (Table 3 ).

Considering soil microhabitats, we did not observe clear significant differences in the number of species, with the exception of bare soil during the dry season, where the species of amoeboid protists decreased below detection level ( $\mathrm{P}<0.05$; Fig. 2). Additionally, when comparing morphotypes, it was observed that during the wet season, the number of protist species with eruptive morphotypes decreased, and only during this season did the lingulate morphotype appear (Fig. 2).

The rarefaction curves showed that during the dry season, the richness was higher in soils protected by the canopy of shrubs than in bare soil (Fig. 3a). This protist diversity pattern, however, was absent during the wet season because amoeboid protist richness was similar in both soils protected by the canopy of shrubs and bare soils (Fig. 3b).

The Sørensen analysis showed a similarity of $80 \%$ between the species of protists existing in the dry and wet seasons. We found 25 species during the dry season and 20 during the rainy season. Of all species, 18 were detected in both seasons, 7 were present only during the dry season, and only 2 were detected during the wet season.

\section{Correlation analyses}

The CCA showed that the correlation between amoeboid protists and soil parameters varied depending on the season (Fig. 4, Table 4). In the dry season, the first and second canonical axes explained $21-33 \%$ of the total variance. In the wet season, the first and second canonical axes explained $17-28 \%$ of the total variance (Fig. 4). The electrical conductivity $(\mathrm{P}=0.011)$ and $\mathrm{pH}$ $(\mathrm{P}=0.037)$ were the only soil parameters significantly correlated with protists in the wet season (Fig. 4).

Table 1. Mean and standard deviation of physical and chemical soil parameters (moisture, sand, silt, clay, $\mathrm{pH}$, electrical conductivity (EC), organic matter and orthophosphates under Pr. laevigata (PL), Pa. praecox (PP) and bare soil (BS) during dry and wet seasons. Means that do not share a letter are significantly different $(\mathrm{P}<0.05)$.

\begin{tabular}{|c|c|c|c|c|c|c|}
\hline & & Dry & & & Wet & \\
\hline Soil property & PL & PP & BS & PL & PP & BS \\
\hline Moisture (\%) & $8.3 \pm 0.5 \mathrm{a}$ & $13.8 \pm 2.2 b$ & $7.0 \pm 0.4 \mathrm{a}$ & $15.0 \pm 2.1 \mathrm{~b}$ & $6.4 \pm 0.6 \mathrm{a}$ & $8.8 \pm 0.9 \mathrm{a}$ \\
\hline Sand $(\%)$ & $43.2 \pm 2.1 b$ & $36.8 \pm 1.6 \mathrm{a}$ & $32.7 \pm 5.2 \mathrm{a}$ & $39.2 \pm 1.5 \mathrm{ab}$ & $44.6 \pm 3.2 b$ & $36.2 \pm 2.0 \mathrm{a}$ \\
\hline Silt (\%) & $33.4 \pm 2.4 b$ & $40.6 \pm 1.6 \mathrm{a}$ & $42.9 \pm 4.7 \mathrm{a}$ & $39.5 \pm 1.3 \mathrm{ab}$ & $35.4 \pm 2.9 b$ & $41.0 \pm 1.9 \mathrm{a}$ \\
\hline Clay (\%) & $23.4 \pm 1.2$ & $22.6 \pm 1.4$ & $24.4 \pm 1.2$ & $21.3 \pm 0.7$ & $20.0 \pm 1.2$ & $22.8 \pm 0.7$ \\
\hline $\mathrm{EC}\left(\right.$ millimhos $\left.\mathrm{cm}^{-1}\right)$ & $1.1 \pm 0.3$ & $1.7 \pm 0.4$ & $0.5 \pm 0.2$ & $2.3 \pm 0.7$ & $4.6 \pm 0.9$ & $4.6 \pm 1.0$ \\
\hline $\mathrm{pH}$ & $7.7 \pm 0.0 \mathrm{~b}$ & $7.6 \pm 0.1 b$ & $8.3 \pm 0.3 \mathrm{a}$ & $7.7 \pm 0.1 b$ & $7.7 \pm 0.0 \mathrm{~b}$ & $7.4 \pm 0.1 \mathrm{a}$ \\
\hline Organic matter $(\%)$ & $2.7 \pm 0.2 \mathrm{~b}$ & $1.7 \pm 0.2 \mathrm{a}$ & $1.6 \pm 0.5 \mathrm{a}$ & $1.7 \pm 0.2$ & $1.7 \pm 0.1$ & $1.5 \pm 0.1$ \\
\hline Ortophosphates $\left(\mathrm{mg} \mathrm{kg}^{-1}\right)$ & $5.2 \pm 0.6$ & $4.0 \pm 0.3$ & $3.0 \pm 0.4$ & $4.2 \pm 0.3$ & $3.8 \pm 0.1$ & $3.9 \pm 0.2$ \\
\hline
\end{tabular}


Table 2. Statistical effect [F-value (d. f., P-value)] of season and habitat within season for different soil properties using linear mixed effect models with nesting.

\begin{tabular}{lll}
\hline Soil property & Season & $\begin{array}{l}\text { Microhabitat (Season) } \\
\text { F (d. f., P) }\end{array}$ \\
\hline Moisture (\%) & F (d. f., P) & $8.4(4,12,0.002)$ \\
Sand (\%) & $0.1(1,41,0.7)$ & $3.6(4,10,0.05)$ \\
Silt (\%) & $1.4(1,41,0.2)$ & $5.0(4,10,0.02)$ \\
Clay (\%) & $0.06(1,41,0.8)$ & $0.8(4,14,0.6)$ \\
Electrical conductivity (millimhos cm $\left.{ }^{-1}\right)$ & $3.6(1,41,0.06)$ & $1.2(4,11,0.4)$ \\
pH & $13.6(1,41,0.0006)$ & $5.5(4,14,0.007)$ \\
Organic matter (\%) & $16.6(1,41,0.0002)$ & $3.4(4,14,0.04)$ \\
Ortophosphates $\left(\mathrm{mg} \mathrm{kg}^{-1}\right)$ & $3.3(1,41,0.08)$ & $2.5(4,14,0.09)$ \\
\hline
\end{tabular}

\section{DISCUSSION}

The Tehuacán desert exhibits variation in the amoeboid protist community concomitant with marked seasonal changes. Bare soil amoeboid protists were strongly affected by seasonal changes because during the dry season, there was a drastic decrease in their richness, except for Heterolobosea, whereas amoeboid richness remained constant underneath both $P a$. praecox and $P r$. laevigata desert shrubs in wet and drought conditions. It has been shown that desert shrubs modify the soil physical and chemical parameters under their canopies (Serrano-Vázquez et al. 2013).

In this study the $\mathrm{pH}$ was the only edaphic factor that was modified by the two shrubs in wet or drought conditions, in contrast to the bare soil. In addition, we found a correlation with the $\mathrm{pH}$ and electrical conductivity of soil that likely explains shifts in the diversity of amoeboid protist species. The $\mathrm{pH}$ and electrical conductivity could play a key role in the availability of nutrients in the soil (Stewart and Tiessen 1987, Braschi et al. 2003). In soils with alkaline $\mathrm{pH}$, mineral complexes with nutrients may be produced, making them unavailable to plants and many microorganisms (Tunesi et al. 1999), as a consequence of evapotranspiration and salt accumulation that increase the electrical conductivity (Li et al. 2011, Serrano-Vázquez et al. 2013).

Thus, the $\mathrm{pH}$ and electrical conductivity are important in the microbial communities distributed in the soil (Avis et al. 2008, Puignare et al. 2004) and, consequently, in the diversity patterns of many microeukaryotes, including amoeboid protists ( $\mathrm{Li}$ et al. 2018, Shen et al. 2014). In addition, remaining moisture, relatively moderate temperatures, and nutrient input from dead leaves are certainly favorable conditions for many amoeboid protists that inhabit the microhabitats with vegetation (Robinson et al. 2002).

It can therefore be reasonably assumed that shrub canopies act as refugia for many protist species during the dry season in contrast to the bare soil. During the dry season, the community of protists in bare soils was poor, in contrast to the diversity found underneath shrubs. Additionally, all species found in bare soil samples also occurred in the samples from under shrubs and were almost only Heterolobosea. This pattern of diversity has been previously reported for protists from other hot deserts (Robinson et al. 2002, Bamforth 2008, Fernández 2015). This suggests that this pattern of diversity is the result of nonrandom mechanisms, such as those mediated by a source-sink dynamics process (Fernández 2015). Most likely, during the wet season, bare soils were only colonized by generalist species with particular traits that allowed them to survive (but not to establish permanent populations) in these harsh soils.

It has recently been shown that protist composition also responds to changes in soil moisture, especially regarding larger protists, which quickly disappear with decreasing soil moisture content (Geisen et al. 2014). Most Amoebozoa and Rhizaria follow this pattern; in contrast, Heterolobosea does not seem affected by seasonal changes and can be found both under bare soils and canopies in any season. Heterolobosea includes several thermophilic species and seems phylogenetically well adapted to extreme heat, as is the case for some marine species and soil organisms (Dobson et al. 1997; De Jonckheere et al. 2011a, b). They are known to respond quickly to rain pulses by explosive growth 
H. Pérez-Juárez et al.

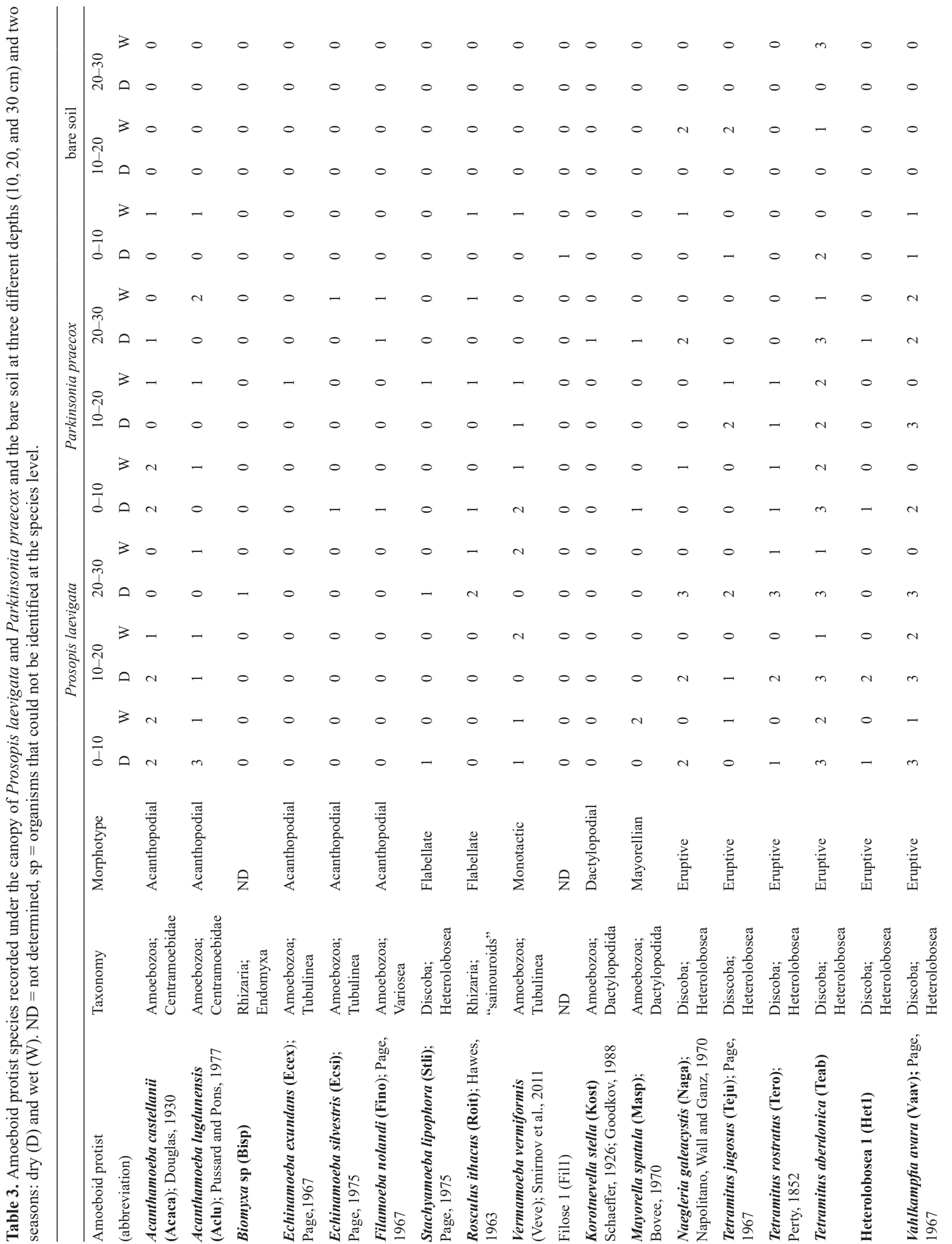




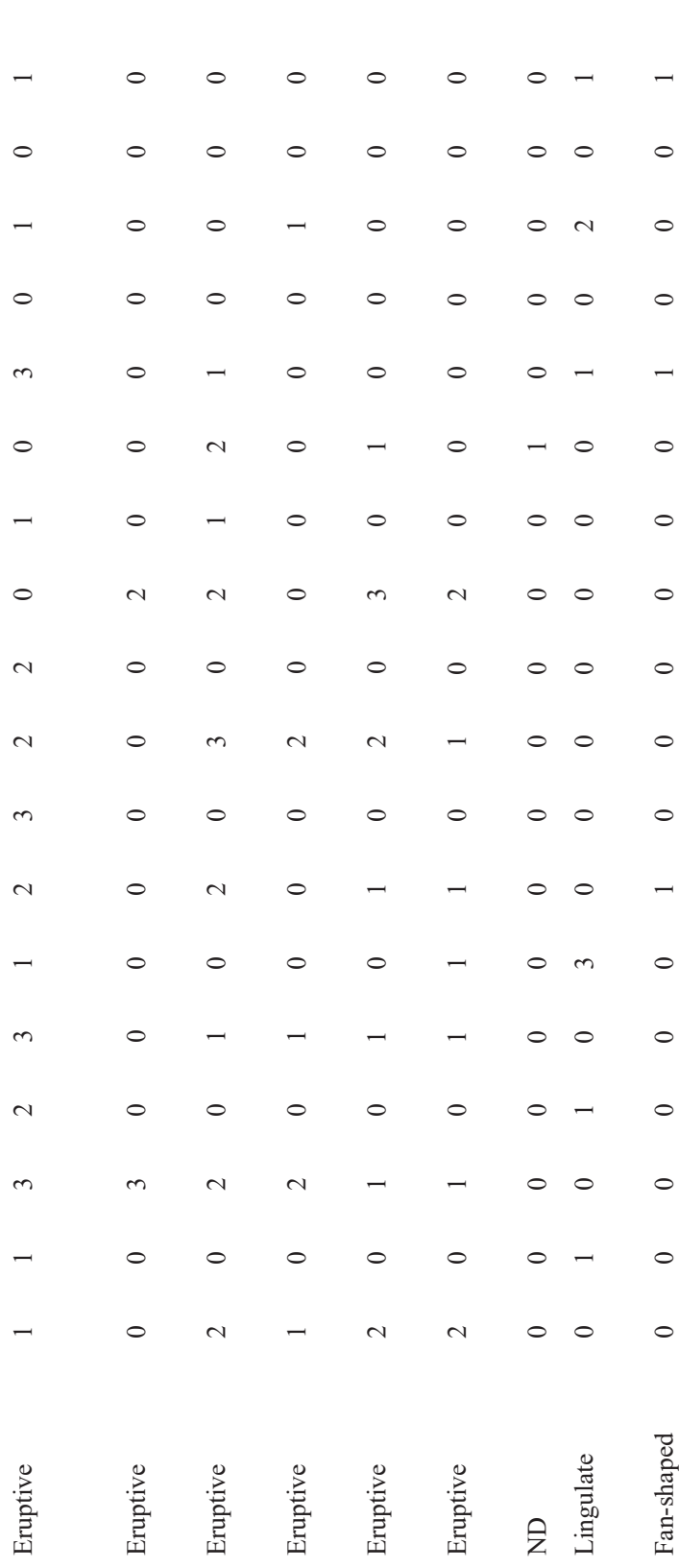
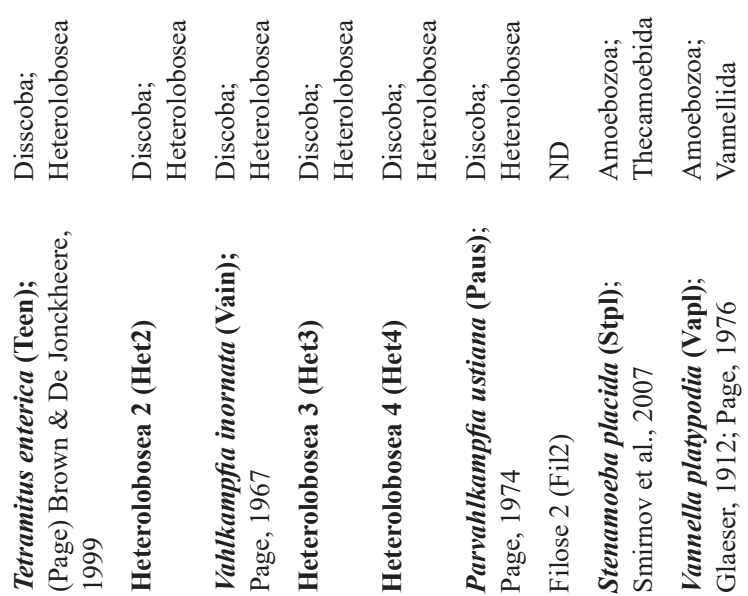

episodes (Bass and Bischoff 2001). This strategy seems well suited to desert soils, and these organisms are commonly found in these environments (Ekelund and Ronn 1994, Foster and Dormaar 1991, Bass and Bischoff 2001). Heterolobosea seem therefore to be very competitive in desert environments and to have welladapted year-round resident populations in deserts (Bass and Bischoff 2001). This idea is supported by the observation that protists with Heterolobosean morphology (i.e., eruptive amoebae) have been recorded in several hot deserts across several continents (Robinson et al. 2002, Mayzlish-Gati and Steinberger 2007, Dumac et al. 2016).

Because Heterolobosea is the group that is more diverse in this desert, we suggest that heat positively selects for it against other protists in desert soils, but experiments and additional studies are needed to explore this idea. However, we suggest that these protists can withstand adverse desert conditions by entering a dormant life stage (i.e., cysts), while their other life states help them to survive during active stages in the dry and heat of desert conditions. Additionally, although many soil protists are capable of producing cysts, these structures have different morphological, physiological and persistence parameters and resist different adverse conditions (Geisen et al. 2018); thus, the cysts of Heterolobosea could be more resistant than the other soil protists. The exact identity of these Heterolobosea still remains to be determined, as this group contains many forms that cannot be distinguished by morphology alone (Anderson et al. 2011, Harding et al. 2013, Geisen et al. 2015). Molecular makers should be helpful to analyze the identities and diversity of this important protist group in future research.

\section{CONCLUDING REMARKS}

In strong agreement with previous studies, our study showed that in deserts, soil beneath shrubs exhibit richer soil protist communities than bare soils. This is very likely because shrubs provide shelter and other conditions that promote the development of soil amoeboid protists.

We also found that the species were distributed homogeneously during the wet season; however, the less resistant species died or their populations decreased considerably in the bare soil during the dry season, but 
Table 4. Correlation (CCA) between protist amoeboid species and soil properties matrix during wet season ( $\mathrm{P}$ values based on 999 permutation. $*=\mathrm{P}<0.05)$.

\begin{tabular}{lcclc}
\hline Soil property & CA1 & CA2 & r2 & Pr $(>$ r) \\
\hline Moisture & -0.69778 & -0.71631 & 0.0973 & 0.313 \\
Sand & 0.94794 & -0.31844 & 0.024 & 0.738 \\
Silt & -0.68819 & -0.72553 & 0.0514 & 0.508 \\
Clay & -0.13104 & 0.99138 & 0.2244 & 0.067 \\
Electrical conductivity & 0.01926 & 0.99981 & 0.3154 & $0.015 *$ \\
pH & 0.17476 & -0.98461 & 0.2409 & $0.039 *$ \\
Organic matter & -0.85677 & -0.5157 & 0.1798 & 0.099 \\
Ortophosphates & -0.4224 & -0.90641 & 0.198 & 0.095 \\
\hline
\end{tabular}

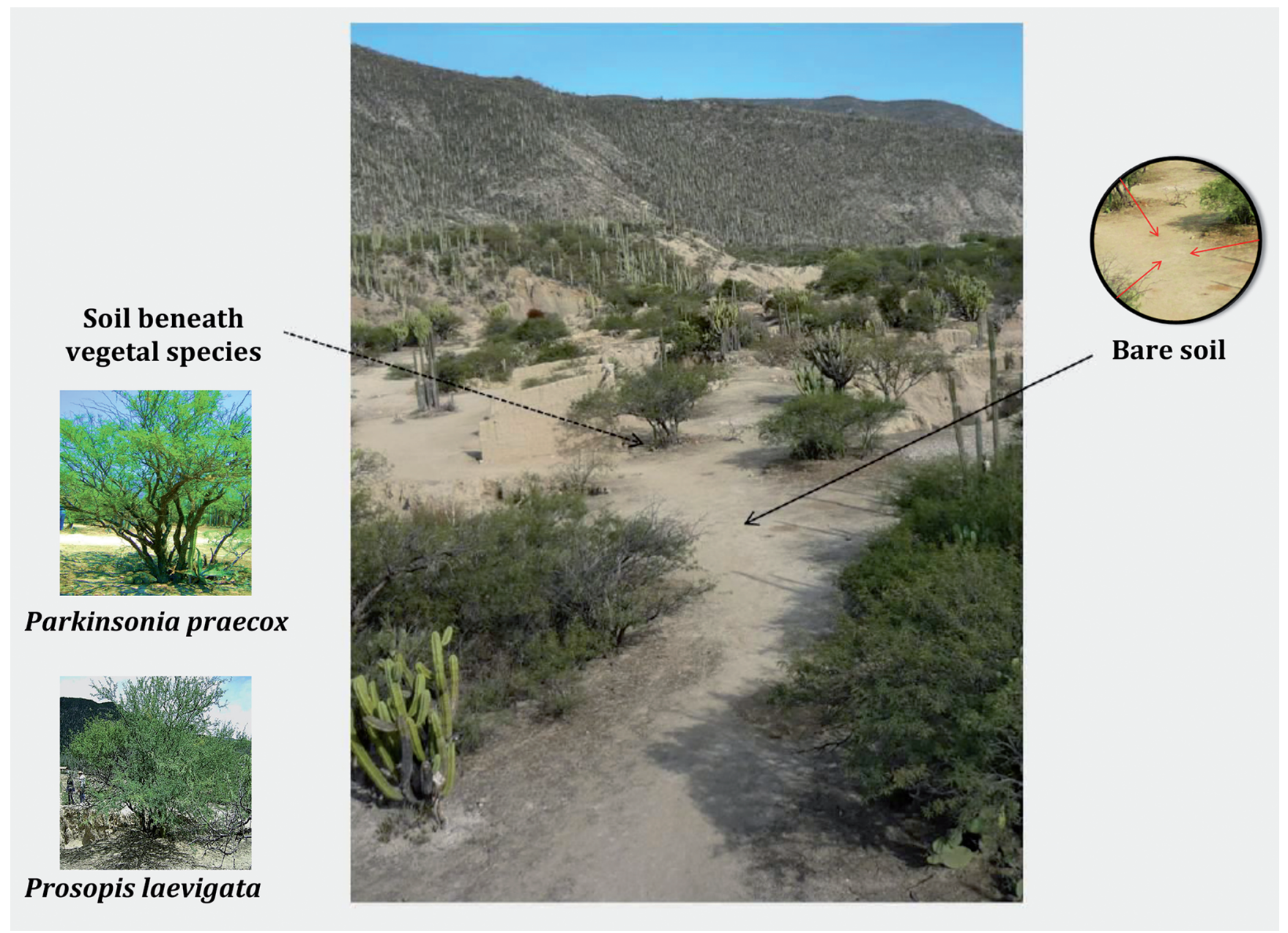

Figure 1. Study area, showing vegetation patches in the desert of Tehuacán, Puebla, Mexico. In addition, the analyzed microhabitats are shown: Pr. laevigata, Pa. praecox and bare soil. 


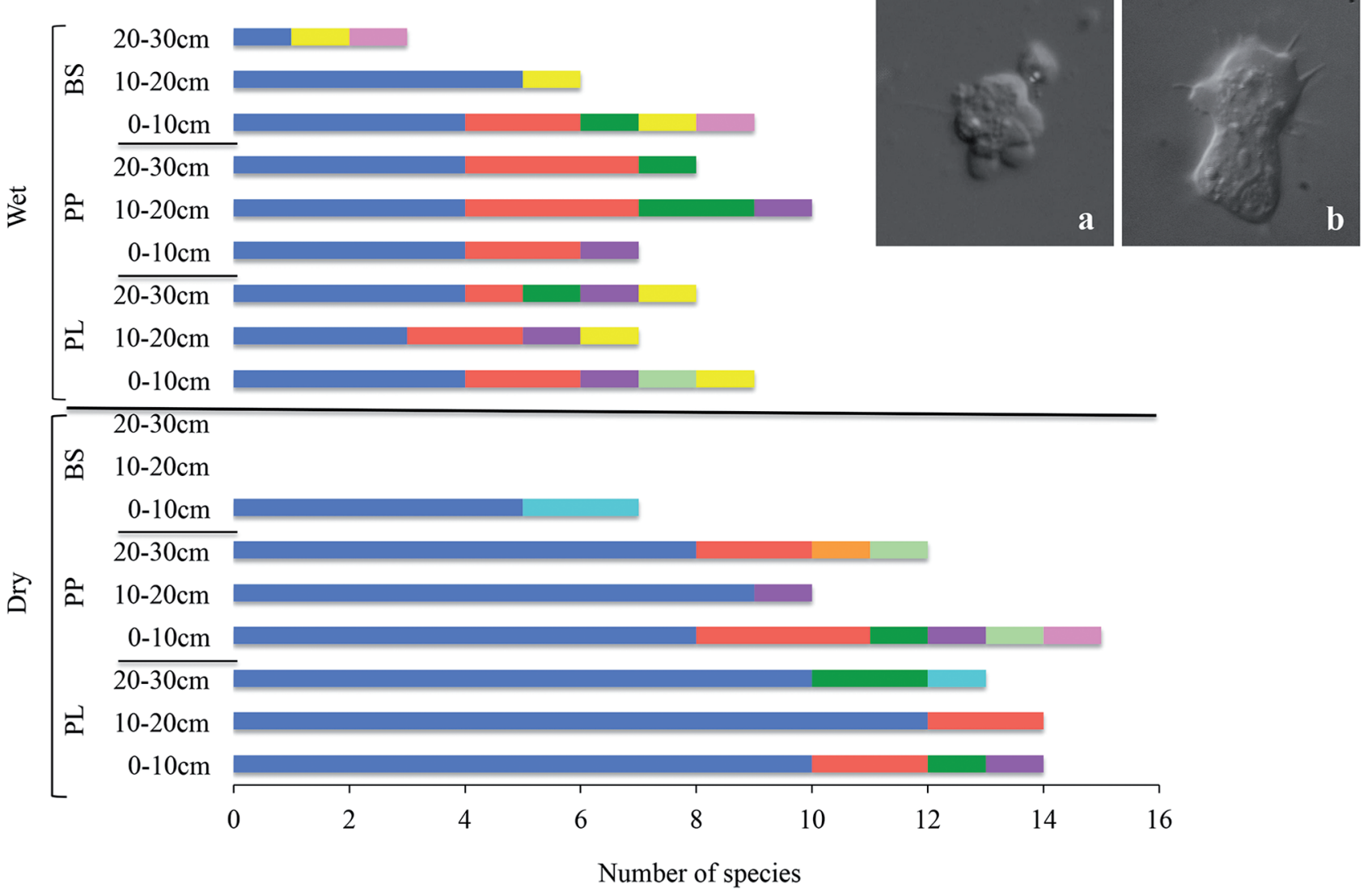

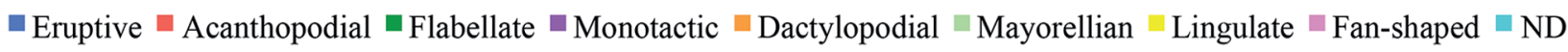

Figure 2. Cumulative richness plots of amoeboid protists present under Pr. laevigata (PL), Pa. praecox (PP) and bare soil (BS) during dry and wet seasons at $0-30 \mathrm{~cm}$. a) eruptive pseudopods, and b) acanthopodial pseudopods. ND: not determined.

they persisted under two desert shrubs that we investigated, which acted as refugia.

Finally, we remark that thermophilic Heterolobosea can withstand adverse conditions (i.e., heat and low moisture) during all seasons and probably constitute the resident population of heterotrophic protists in many deserts. Given the essential role played by small heterotrophic protists in soils, Heterolobosea are most likely to constitute keystone organisms in arid ecosystems.

Acknowledgments. Horacio Pérez Juárez is a doctoral student from Programa de Doctorado en Ciencias Biomédicas, Universidad Nacional Autónoma de México (UNAM) and received fellowship 408467/262505 from CONACYT. The present manuscript constitutes a partial fulfillment of the Graduate Program.

The authors are grateful for the funds provided by the UNAMDGAPA-PAPIIT- IN217112 project (Structuring of microbial com- munities in soil of legumes, cacti, and biological crusts in Zapotitlán Salinas, Puebla), to the project PAPCA-UNAM-2013-2014 (Dinámica espacial de la comunidad de amebas desnudas de vida libre del suelo bajo Pr. laevigata y Pa. praecox en una terraza degradada de Zapotitlán Salinas, Puebla), to CONACYT (No. 272601) and the Swiss National Fund (grant No. SNF 31003A_163254 to EL). L.D.F. is supported by projects FONDECYT (No. 11170927) and UBO/VRIP (No. 170201). We also thank Jesús Bazán Cuenca, Isabel Antonio and Abbid Hernández for their technical assistance in the physical and chemical analysis. We also thank Tobias Portillo, Jesús Pérez Juárez and Marco Gudiño for their assistance in the figure renditions and to Humberto Macías Cuellar and all participants of IN217112 and PAPCA-UNAM-2013-2014 projects by their support in the field. We thank Alicia Valadez, Enrique Gonzalez, Eric Hernández, Miriam Nieves, Ulises Magaña and Oswaldo Partida for their assistance in the laboratory work and in the culture of microorganisms. We also wish to express our thanks to the authorities of the Zapotitlán Salinas and in particular to Mr. Pacheco, Puebla, for his permission and help provided in the field. 

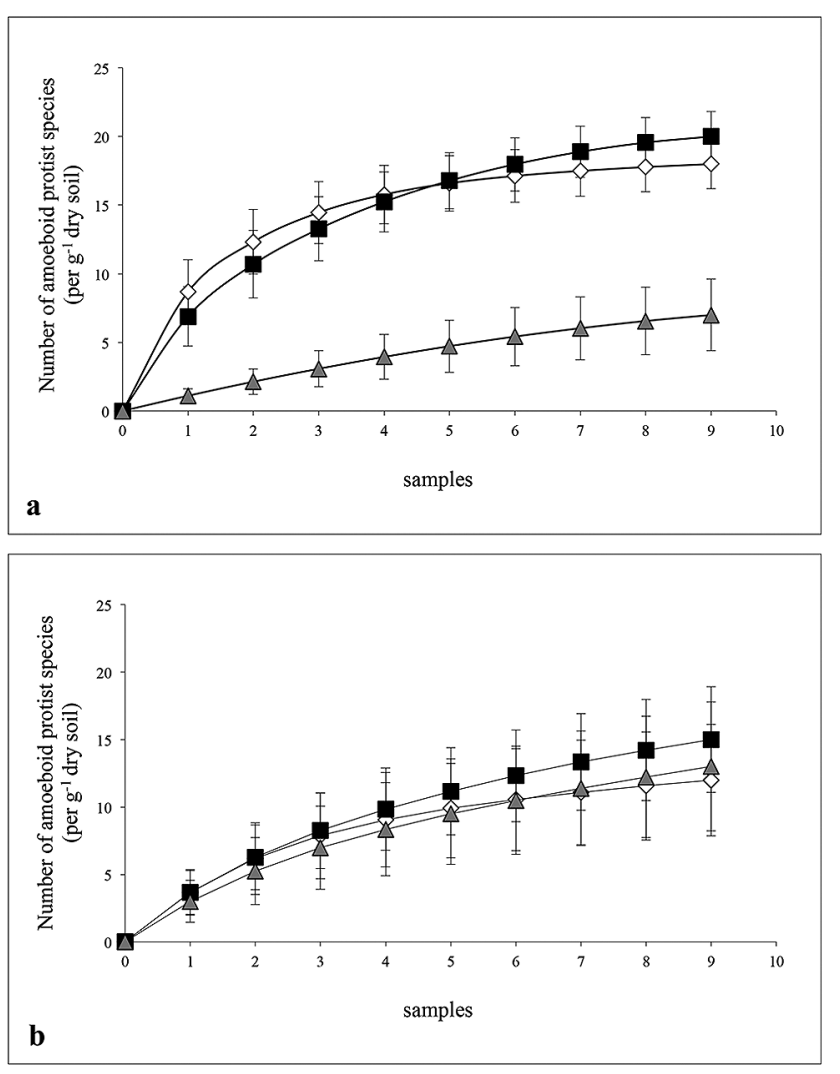

1 Figure 3. Rarefaction curves of number of species of amoeboid protists by different microhabitats: Pr. laevigata (diamonds), $P a$. praecox (squares), and bare soil (triangles) in a) dry and b) wet season (error bars are $95 \% \mathrm{CI})$.

₹ Figure 4. Relationship between amoeboid protist richness and soil parameters during the wet season in three microhabitats by CCA: PL: Pr. laevigata, PP: Pa. praecox, and BS: bare soil. The names and abbreviations of the amoeboid protist species can be found in table 3 .

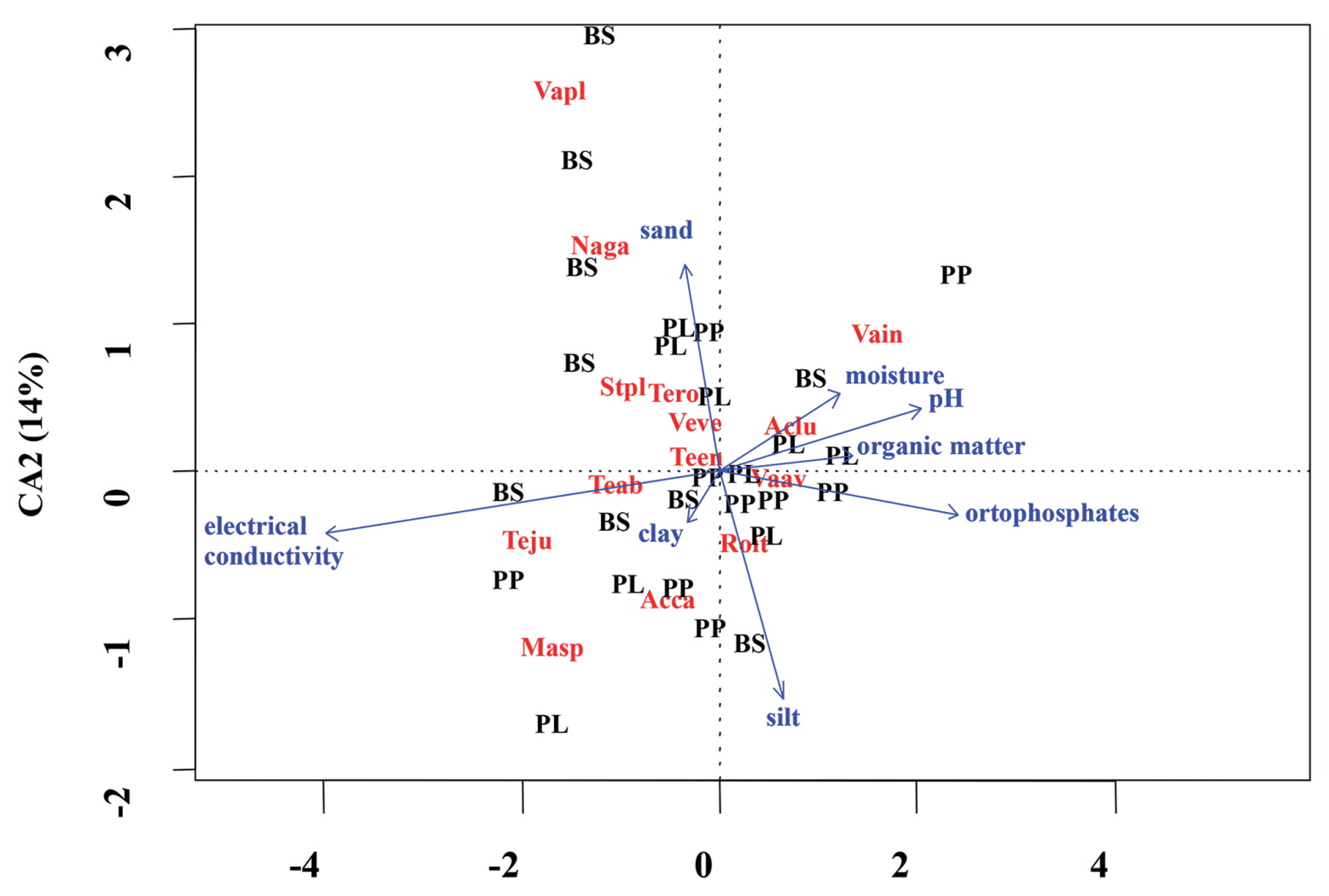

CA1 (17\%) 
Finally, we thank the anonymous reviewers for their helpful comments and suggestions to improve the manuscript. The manuscript was written during a sabbatical leave of LEE while at the University of Minnesota, Department of Plant and Microbial Biology, in Peter Tiffin's laboratory, with support of the program PASPADGAPA, UNAM. We highly appreciate the design of graphical material for this paper by Maria de Lourdes Alonso for work on Figs. 1, 2, 3 and 4 of this manuscript.

\section{REFERENCES}

Adl S. M., Simpson A. G., Lane C. E., Lukeš J., Bass D., Bowser S. S., Brown M. W., Burki F., Dunthorn M., Hampl V., Heiss A., Hoppenrath M., Lara E., Le Gal L., Lynn D. H., McManus H., Mitchell A. D. E., Mozley-Stanridge S. E., Parfrey L. W., Pawlowski J., Rueckert S., Shadwick L., Schoch C. L., Smirnov A., Spiegel F. W. (2012) The revised classification of eukaryotes. J. Eukaryot. Microbiol. 59: 429-514

Adl S. M., Bass D., Lane C. E., Lukeš J., Schoch C. L., Smirnov A., Agatha S., Berney C., Brown M. W., Burki F., Cardenas P., Cepicka I., Chistyakova L., del Campo J., Dunthorn M., Edvarsen B., Eglit Y., Guillou L., Hampl V., Heisss A. A., Hoppenrath M., James T. Y., Karpov S., Kim E., Kolisko M., Kudryavtsev A., Lahr D.J.G., Lara E., Le Gall L., Lynn D. H., Mann D. G., Massana R., Mitchell A. D. E., Morrow C., Soo, J., Pawlowski J., Powell M. J., Richter D. J., Rueckert S., Shadwick L., Shimano S., Spiegel F. W., Torruella G., Youssef N., Zlatogursky V., Zhang Q. (2018) Revisions to the classification, nomenclature, and diversity of eukaryotes. J. Eukaryot. Microbiol. https://doi. org/10.1111/jeu. 12691

Anderson O. R. (2000) Abundance of terrestrial gymnamoebae at a northeastern U. S. site: A four-year study, including the El Nino winter of 1997-1998. J. Eukaryot. Microbiol 47: 148-155

Anderson O. R., Wang W. E. N., Faucher S. P., Bi K., Shuman H. A. (2011) A new heterolobosean amoeba Solumitrus palustris n. g., n. sp. isolated from freshwater marsh soil. J. Eukaryot. Microbiol. 58: 60-67

Austin A.T., Yahdjian L., Stark J.M., Belnap J., Porporato A., Norton U., Ravetta D.A., Schaeffer S.M. (2004) Water pulses and biogeochemical cycles in arid and semiarid ecosystems. Oecologia 141: 221-235

Avis T.J., Gravel V., Antoun H., Tweddell R. (2008) Multifaceted beneficial effects of rhizosphere microorganisms on plant health and productivity. Soil Biol. Biochem. 40: 1733-1740

Bamforth S. S. (1963) Limnetic protozoa of southeastern Louisiana. Proc. Louisiana Acad. Sci. 26: 120-134

Bamforth S. S. (2008) Protozoa of biological soil crusts of a cool desert in Utah. J. Arid Environ. 72: 722-729

Barness G., Rodríguez S., Shmueli I., Steinberger Y. (2009) Vertical distribution of a soil microbial community as affected by plant ecophysiological adaptation in a desert system. Microbiol. Ecol. 57: $36-49$

Bass P., Bischoff P. J. (2001) Seasonal variability in abundance and diversity of soil Gymnamoebae along a short transect in Southeastern USA. J. Eukaryot. Microbiol. 48: 475-479

Bates R. G. (1954) Electrometric pH Determinations. John Wiley \& Sons, Inc.

Bouyoucos G. J. (1962) Hydrometer method improved for making particle size analyses of soils. Agron. J. 54: 464-465

Bonkowski M. (2004) Protozoa and plant growth: the microbial loop in soil revisited. New Phytologist. 162: 617-631
Braschi I., Ciavatta C., Giovannini C., Gessa C. (2003) Combined effect of water and organic matter on phosphorus availability in calcareous soils. Nut Cycl Agroecosys. 67: 67-74

Brown S., De Jonckheere J. F. (1999) A reevaluation of the amoeba genus Vahlkampfia based on SSUrDNA sequences. Eur. J. Protistol. 35: 49-54

Cajuste L. J. (1986) El fósforo aprovechable en los suelos. Cuadernos de Edafología. Vol. 6 Centro de Edafología, Colegio de Postgraduados, México

Colwell R. K. (2013) EstimateS: Statistical estimation of richness and shared species from samples. Version 9

Dávila P., Arizmendi M. D. C., Valiente-Banuet A., Villaseñor J. L., Casas A., Lira R. (2002) Biological diversity in the TehuacánCuicatlán Valley, Mexico. Biod.con, 11: 421-442

De Jonckheere J. F., Baumgartner M., Eberhardt S., Opperdoes F. R., Stetter K. O. (2011a) Oramoeba fumarolia gen. nov., sp nov., a new marine heterolobosean amoeboflagellate growing at 54 degrees C. Eur. J. Protistol. 47: 16-23

De Jonckheere J. F., Murase J., Opperdoes F. R. (2011b) A new thermophilic heterolobosean amoeba, Fumarolamoeba ceboru$c o i$, gen. nov., sp nov., isolated near a fumarole at a volcano in Mexico. Acta Protozool. 50: 41-48

Dobson P. J., Robinson B. S., Rowan-Kelly B. (1997) New thermophilic Naegleria species (Heterolobosea: Vahlkampfiidae) from Australia and Asia: Allozyme, morphometric and physiological characterisation. Acta Protozool. 36: 261-271

Dumack K., Koller R., Weber B., Bonkowski M. (2016) Estimated abundance and diversity of heterotrophic protists in South African biocrusts. S. Afr. J. Sci. 112: 56-60

Ekelund F., Ronn R., (1994) Notes on protozoa in agricultural soil with emphasis on heterotrophic flagellates and naked amoebae and their ecology. FEMS Microbiol. Rev. 15: 321-353

Fahrni J. F., Bolivar I., Berney C., Nassonova E., Smirnov A., Pawlowski J. (2003) Phylogeny of lobose amoebae based on actin and small-subunit ribosomal RNA genes. Mol. Biol. Evol. 20: $1881-1886$

Fernández L. D. (2015) Source-sink dynamics shapes the spatial distribution of soil protists in an arid shrubland of northern Chile. J. Arid Environ. 113: 121-125

Foissner W. (2011) Dispersal of protist: the role of cyst and human introduction. In Biogeography of Microscopic Organisms: is Everything Small Everywhere? Fontaneto D., ed. Systematics Association and Cambridge University Press, Cambridge, UK. pp 61-87

Foster R. C., Dormaar J. F. (1991) Bacteria-grazing amoebae in situ in the rhizosphere. Biol. Fertil. Soils 11: 83-87

Geisen S., Fiore-Donno A. M., Walochnik J., Bonkowski M. (2014) Acanthamoeba everywhere: high diversity of Acanthamoeba in soils. Parasitol. Res. 113: 3151-3158

Geisen S., Bonkowski M., Zhang J., De Jonckheere J. F. (2015). Heterogeneity in the genus Allovahlkampfia and the description of the new genus Parafumarolamoeba (Vahlkampfiidae; Heterolobosea). Eur j protisto, 51: 335-349

Geisen S., Koller R., Hunninghaus M., Dumack K., Urich T., Bonkowski M. (2016) The soil food web revisited: Diverse and widespread mycophagous soil protists. Soil Biol. Biochem. 94: $10-18$

Geisen S., Mitchell E. A. D., Wilkinson D. M., Adl S., Bonkowski M., Brown M. W., Fiore-Donno A. M., Heger T. J., Jassey V. E. J., Krashevska V., Lahr D. J. G., Marcisz K., Mulot M., Payne R., Singer D., Anderson O. R., Charman D. J., Ekelund F., Griffiths B. S., Rønn R., Smirnov A., Bass D., Belbahri 
L., Berney C., Blandenier Q., Chatzinotas A., Clarholm M., Dunthorn M., Feest A., Fernández L. D., Foissner W., Fournier B., Gentekaki E., Hájek M., Helder J., Jousset A., Koller R., Kumar S., La Terza A., Lamentowicz M., Mazei Y., Santos S. S., Seppey C. V. W., Spiegel F. W., Walochnik J., Winding A., Lara E. (2017) Soil protistology rebooted: 30 fundamental questions to start with. Soil Biol. Biochem. 111: 94-103

Geisen S., Mitchell E. A., Adl S., Bonkowski M., Dunthorn M., Ekelund F., Fernández L. D., Jousset A., Krashevska V., Singer D., Spiegel F. W., Walochnik J., Lara E. (2018) Soil protists: a fertile frontier in soil biology research. FEMS Microbiol Rev. 42: 293-323 doi:10.1093/femsre/fuy006

Griffiths B.S., Bonkowski M., Roy J., Ritz K. (2001) Functional stability, substrate utilisation and biological indicators of soils following environmental impacts. Appl. Soil Ecol. 16: 49-61

Lanzén A., Epelde L., Blanco F., Martín I., Artetxe U., Garbisu C. (2016) Multi-targeted metagenetic analysis of the influence of climate and environmental parameters on soil microbial communities along an elevational gradient. Sci rep. 6: 28257

Li C., Li Y., Ma J. (2011) Spatial heterogeneity of soil chemical properties at fine scale induced by Haloxylon ammodendron (Chenopodiaceae) plants in a sandy desert. Ecol. Res. 26: 385394

Li J., Lin J., Pei C., Lai K., Jeffries T. C., Tang G. (2018) Variation of soil bacterial communities along a chronosequence of Eucalyptus plantation. PeerJ, 6, e5648

López-Galindo F., Muñoz-Iniestra D., Hernández-Moreno M., Soler-Aburto A., Castillo-López M. D. C., Hernandez-Arzate I. (2003) Análisis integral de la toposecuencia y su influencia en la distribución de la vegetación y la degradación del suelo en la subcuenca de Zapotitlán Salinas, Puebla. B. Soc. Geol. Mex. 56: $19-41$

Mayzlish-Gati E., Steinberger Y. (2007) Ameba community dynamics and diversity in a desert ecosystem. Biol. Fertil. Soils. 43: 357-366

Medina H., García J., Núñez D. (2007) El método del hidrómetro: base teórica para su empleo en la determinación de la distribución del tamaño de partículas de suelo. Revista Ciencias Técnicas Agropecuarias 16: 19-24

Oksanen J., Blanchet F. G., Kindt R., Legendre P., Minchin P. R., O'hara R. B., Oksanen M. J. (2013) Package 'vegan'. Community ecology package, version, 2.9.

Olsen R. S., Cole V. C., Wantanabe F. S., Dean L. A. (1954) Estimation of available phosphorus in soils by extraction with sodium bicarbonate. United State Department of Agriculture, Washington, DC

Ortiz V. B., Ortiz A. (1980) Edafologia, 3rd ed. Universidad Autónoma Chapingo, México

Osorio-Beristain O., Valiente-Banuet A., Dávila P., Medina R. (1996) Types of vegetation and $\beta$ diversity at the Valle de Zapotitlán de las Salinas, Puebla, Mexico. Bot. Sci. 59: 35-58

Page F. C. (1976) Illustrated key to freshwater and soil amoebae. Freshwater Biol. Ass. Ambleside

Page F. C. (1988) A new key to freshwater and soil gymnamoebae: with instructions for culture. Freshwater Biol. Ass. Ambleside

Pawlowski J., Burki F. (2009) Untangling the phylogeny of amoeboid protists. J. Eukaryot. Microbiol. 56: 16-25

Pérez-Juárez H., Serrano-Vázquez A., Kosakyan A., Mitchell E. A., Aguilar V. M. R., Lahr D. J. G., Hernández M. M. M., Macías C. H., Eguiarte L. E., Lara E. (2017) Quadrulella texcalense sp. nov. from a Mexican desert: an unexpected new environ- ment for hyalospheniid testate amoebae. Eur. J. Protistol. 61: 253-264

Pugnaire F. I., Armas C., Valladares F. (2004) Soil as a mediator in plant-plant interaction in a semi-arid community. J. Veg. Sci. 15: $85-92$

Robinson B. S., Bamforth S. S., Dobson P. J. (2002) Density and diversity of protozoa in some arid Australian soils. J. Eukaryot. Microbiol. 49: 449-453

Rodríguez-Zaragoza S., Steinberger Y. (2004) Seasonal dynamics of amoebae in the root canopy of Zygophyllum dumosum in the Negev Desert, Israel. Pedobiologia 48: 277-281

Rodríguez-Zaragoza S., Mayzlish E., Steinberger Y. (2005a). Vertical distribution of the free-living amoeba population in soil under desert shrubs in the Negev desert, Israel. Appl. Environ. Microbiol. 71: 2053-2060

Rodríguez-Zaragoza S., Mayzlish E., Steinberger Y. (2005b) Seasonal changes in free-living amoeba species in the root canopy of Zygophyllum dumosum in the Negev Desert, Israel. Microb. Ecol. 49: 134-141

Shen C., Liang W., Shi Y., Lin X., Zhang H., Wu X., Xie G., Chain P., Grogan P., Chu H. (2014) Contrasting elevational diversity patterns between eukaryotic soil microbes and plants. Ecology 95: 3190-3202

Seppey C. V., Singer D., Dumack K., Fournier B., Belbahri L., Mitchell E. A., Lara E. (2017) Distribution patterns of soil microbial eukaryotes suggests widespread algivory by phagotrophic protists as an alternative pathway for nutrient cycling. Soil Biol. Biochem. 112: 68-76

Serrano-Vázquez A., Rodríguez-Zaragoza S., Pérez-Juárez H., Bazán-Cuenca J., Rivera-Aguilar V. M., Durán A. 2013. Physical and chemical variations of the soil under two desert shrubs in Tehuacan, Mexico. Soil Sci. 178: 87-103

Smirnov A. V., Brown S. (2004) Guide to the methods of study and identification of soil Gymnamoebae. Protistology 3: 148-190

Stewart J. W. B., Tiessen H. (1987) Dynamics of soil organic phosphorus. Biogeochemistry 4: 41-60

Sylvain Z. A., Wall, D. H. (2011) Linking soil biodiversity and vegetation: Implications for a changing planet. Am. J. Bot. 98: $517-527$

Tunesi S., Poggi V., Gessa C. (1999) Phosphate adsorption and precipitation in calcareous soils: The role of calcium ions in solution and carbonate minerals. Nutr. Cycl. Agroecosyst. 53: 219-227

Valiente-Banuet A., Casas A., Alcántara A., Dávila P., FloresHernández N., del Coro Arizmendi M., Ramírez J.O., (2000) The vegetation of the Valley of Tehuacan-Cuicatlan. Bot. Sci. 67: $25-74$

Villaseñor J. L., Davila P., Chiang F. (1990) Fitogeografía del valle de Tehuacán-Cuicatlán. (Phytogeography of the Tehuacan-Cuicatlan valley). Bol. Soc. Bot. Mex. 50: 135-149

Walkley A., Black I. A. (1934) An examination of the Degtjareff method for determining soil organic matter, and a proposed modification of the chromic acid titration method. Soil sci. 37: 29-8

Whitford W. G. (2002) Ecology of desert systems. Academic Press, London, UK

Willard H. H., Merritt L. L., Dean J. A. (1958). Instrumental Methods of Analysis, 3rd ed. Van Nostrand, Princeton, USA

Received on $19^{\text {th }}$ September, 2018; revised on $22^{\text {nd }}$ November, 2018; accepted on $18^{\text {th }}$ December, 2018 